\title{
Mapping Road Traffic Crashes in Sfax Governorate (Tunisia)
}

\author{
Mongi Belarem ${ }^{1,2}$ (1) \\ ${ }^{1}$ Department of Geography and GIS, Faculty of Humanities and Arts, King Abdulaziz University, Jeddah, KSA \\ ${ }^{2}$ Syfacte Research Laboratory, Department of Geography, Faculty of Humanities and Arts, University of Sfax, ATCIG, Sfax, Tunisia \\ Email: aremmongi@yahoo.fr
}

How to cite this paper: Belarem, M. (2022) Mapping Road Traffic Crashes in Sfax Governorate (Tunisia). Open Journal of $A p$ plied Sciences, 12, 19-41.

https://doi.org/10.4236/ojapps.2022.121003

Received: October 23, 2021

Accepted: January 9, 2022

Published: January 12, 2022

Copyright (c) 2022 by author(s) and Scientific Research Publishing Inc. This work is licensed under the Creative Commons Attribution International License (CC BY 4.0).

http://creativecommons.org/licenses/by/4.0/

\begin{abstract}
Sfax is one of the Tunisian governorates with a large number of road accidents, injuries and fatalities every year. This study aimed to analyze and map traffic accidents in this governorate. We analyzed the spatial distribution of accidents, their distribution by cause, by type of road, by size of traffic, by months of the year and days of the week. Accidents were correlated with several variables such as population numbers and densities, motorization rate, length and structure of the road network, and the amount of traffic. On the cartographic level, we have built a database, through which we have produced a series of thematic maps to argue this analysis. Through cartographic production, we also aimed to help road users, decision-makers and researchers in this area and in the field of transport. This work showed that Sfax occupies, among the other Tunisian governorates, an advanced position in gravity. Various human, climatic and technical factors explained this situation, of which human factors were the most important, and contributed to almost $90 \%$ of accidents. The current situation of accidents in Sfax requires a series of measures and actions to alleviate and mitigate the gravity of this phenomenon.
\end{abstract}

\section{Keywords}

Road Traffic Crashes, Mapping, Sfax Governorate

\section{Introduction}

According to statistics published in 2018 by the World Health Organization [1], "the road is the eighth cause of death worldwide in 2016" [2]. Road accidents resulted in 1.35 million deaths this year alone, the majority of which are male. According to WHO forecasts, if no radical action is taken on road safety by 
2030, traffic accidents will become the fifth leading cause of death worldwide, with nearly 2.5 million people dying each year on the roads [3].

In Tunisia, as in the other Third World countries, the question of accidentology remains little studied. However, in developed countries, it is well treated. The work of Vandersmissen and al [4] [5] [6] and Cynthia Boucher [7] in Canada, Abdulhafedh, A. [8] in the USA, Moellering Baker [9], Susan et al [10] in the United States and those of Whitelegg in Great Britain [11], although the angles of analysis are diverse, identify good examples of study in this area.

Like the whole of Tunisia, road traffic accidents, in the governorate of Sfax, are a very serious phenomenon, but have specific characteristics linked to several factors such as urban structure, density, structure and length of the road network, modal distribution of transport flows, traffic density, motorization rate, population weight, human factor, weather and technical factors...

In this paper, we discuss the spatial and temporal distribution of accidents in Sfax governorate and the factors determining this phenomenon. We build a database related to the accident, to produce a series of thematic maps and graphs that facilitate and argue the analysis of this phenomenon. In the first part, we present the study area, the tools and the working methodology. In the second part, we analyze the spatial and temporal distribution of accidents by presenting the various explanatory factors. Finally, and through the conclusion, we present a series of findings and recommendations that help decision-makers, stakeholders and researchers in the fields of accidentology, management and development of road networks and road traffic in the governorate of Sfax and in Tunisia.

\section{Study area and Methodology}

The study area is the governorate of Sfax which is located in the Central East of Tunisia (Figure 1). This coastal governorate comprises 16 delegations, 25 municipalities and 125 Imadats (the smallest unit of the Tunisian administrative division) [12] [13] [14]. It has a surface area of $7545 \mathrm{~km}^{2}$. It has 955,421 inhabitants (with 595,700 inhabitants in cities). The density of this governorate is 126 inhabitants $/ \mathrm{km}^{2}$ [14] [15] [16] [17].

To study the issue of accidents, we used statistics, relating to the Sfax governorate of the year 2020, from the National Observatory of Information, Training, Documentation and Studies on Road Safety (NORS). The data relating to accidents in the agglomeration of Sfax comes from the Civil Protection. These statistics are very precise by date (day and time) and by distance from the center of city. The number of accidents, injuries and deceased, covering the entire $\mathrm{Tu}$ nisian territory, is provided by the NORS in 2020. Data relating to the motorization, traffic and structure of the road network are extracted from the Sfax Atlas, the Sfax Transport Master Plan (1996), the Sfax City Traffic Study (1998), the Transport Master Plan Update Study (2005) and the National Statistical Institute (NSI). Finally, all demographic data are provided by the NSI. All data are entered into a database of a Geographical Information System (GIS). We used 


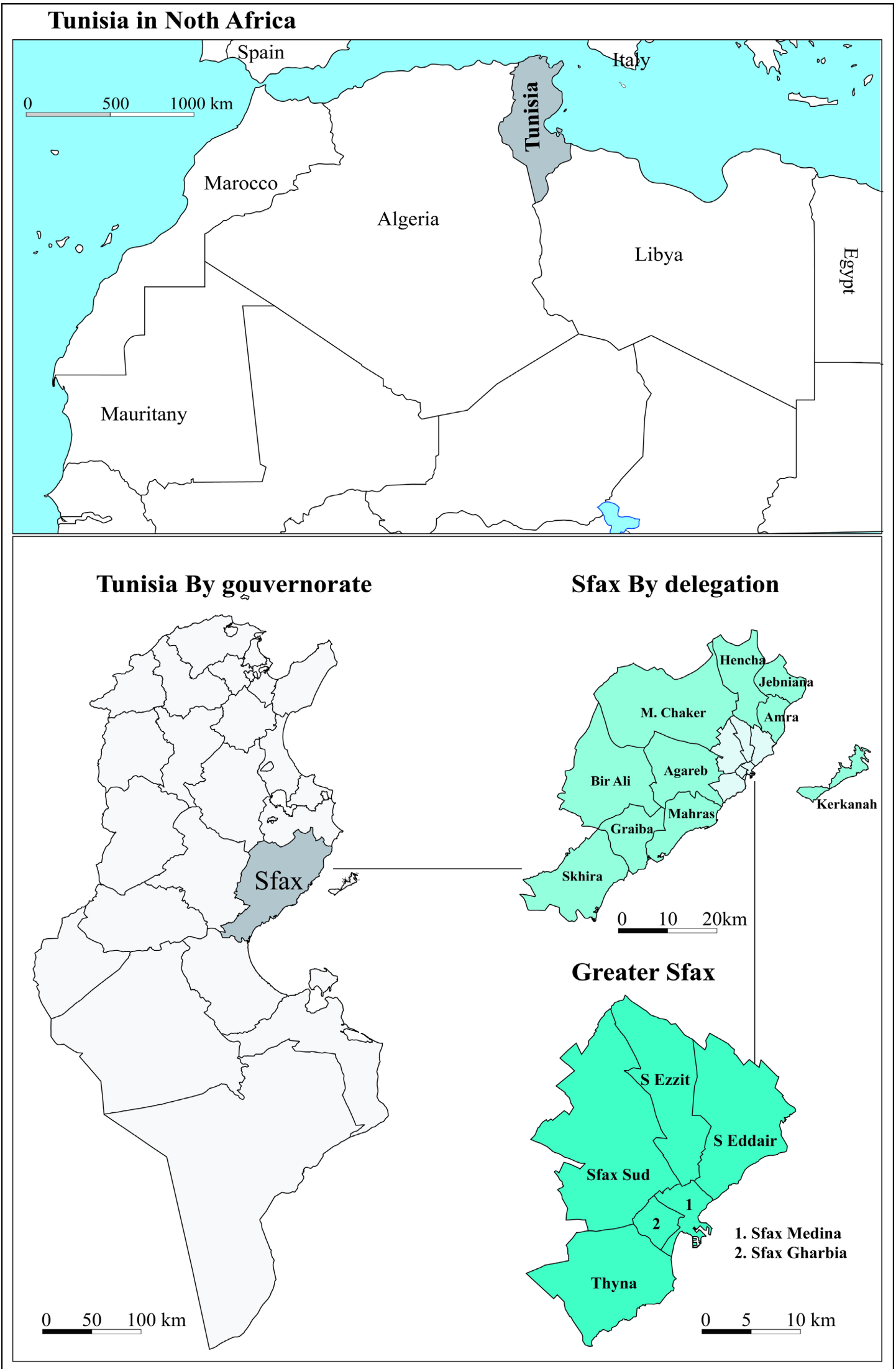

Figure 1. Study area. 
Phildigit for the drawing of base map backgrounds, Philcarto and ArcMap for the creation of thematic maps and Adobe Illustrator for the layout of maps. We also used Microsoft Excel to generate some charts

\section{Results and Discussion}

We deal with the issue of accidents in the governorate of Sfax, through the distribution of traffic accidents, injuries and deceased by delegation, type of road, causes, month, day and by means of transport. The variable traffic accidents will be correlated with other variables such as population (number and density), urbanization rate, roads (length and density), traffic intensity and motorization rate.

\subsection{Spatial Distribution of Traffic Accidents, Injuries and Deceased}

"Over the past 30 years, Tunisian roads have recorded varying results in terms of accidents, injuries and deceased. As a result, the number of car accidents increased from 10,209 in 1996 to 10,980 in 2006" to 5972 accidents with 8574 injuries and 1150 deceased in 2020 [18] [19]. The impact of the Covid-19 crisis on all road safety indicators was very significant compared to 2019 [20], with fewer accidents $(-20.06 \%)$, fewer deceased $(-19.05 \%)$ and fewer injuries $(-21.13 \%)$ (Table 1).

At the national level, the governorate of Sfax ranks fourth in number of accidents, after the governorates of Tunis, Ben Arous and Nabeul, with 258 accidents. This represents $5.4 \%$ of accidents in the country as a whole in 2020 (Figure 2 and Figure 3). The density of accidents in this governorate is relatively low compared to the governorates of Greater Tunis (Tunis, Mannouba, Ariana and Ben Arous). As for the wounded, Sfax also ranks fourth after the capital Tunis, Nabeul and Ben Arous, with 370 wounded (Figure 4). Figure 4 represents almost $6 \%$ of all wounded in the country. The rank of Sfax fits perfectly with that relative to the number of accidents, with an average of 1.5 injured for each accident occurred in the governorate. Admittedly, in 2020, Sfax ranks second in number of deaths due to traffic accidents, after the capital Tunis. The damage of the accidents in Sfax is very catastrophic compared to those in most other governorates, that is one death every three days. The number of deaths in Sfax was 88. It represents nearly $10 \%$ of all deaths in the national territory (Figure 5). This can be explained, even in part, by the high number of accidents and by the

Table 1. Comparison of accidents and their victims between 2020 and 2019. Source: [18].

\begin{tabular}{cccc}
\hline The date & Accidents & Deceased & Injured \\
\hline From 1/1/2019 to 31/12/2019 & 5972 & 1150 & 8574 \\
From 1/1/2020 to 31/12/2020 & 4774 & 931 & 6762 \\
Difference & -1198 & -219 & -1812 \\
Percentage & -20.06 & -19.04 & -21.13 \\
\hline
\end{tabular}




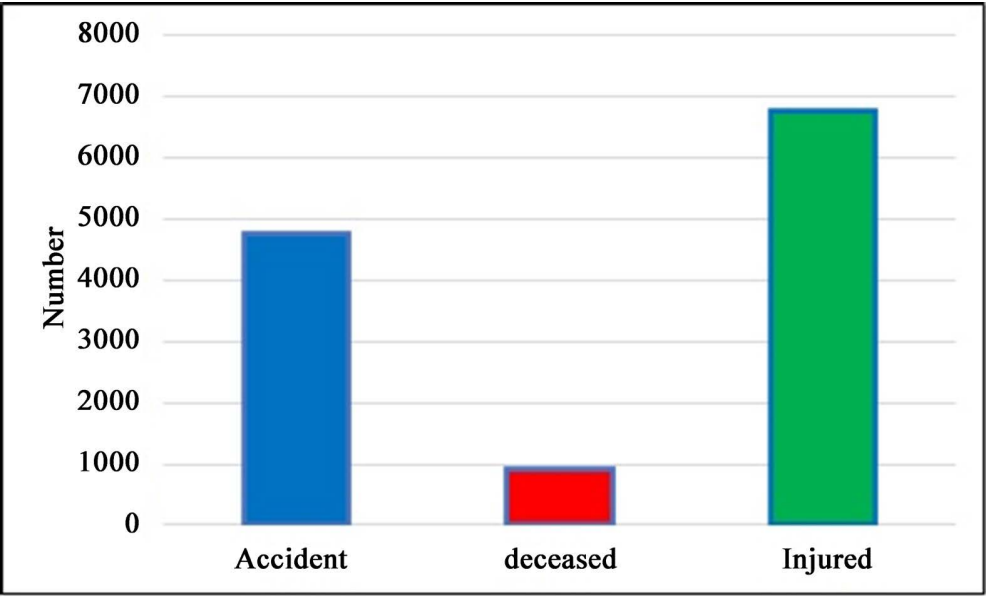

Figure 2. Accidents, injuries and deceased in Tunisia in 2020.

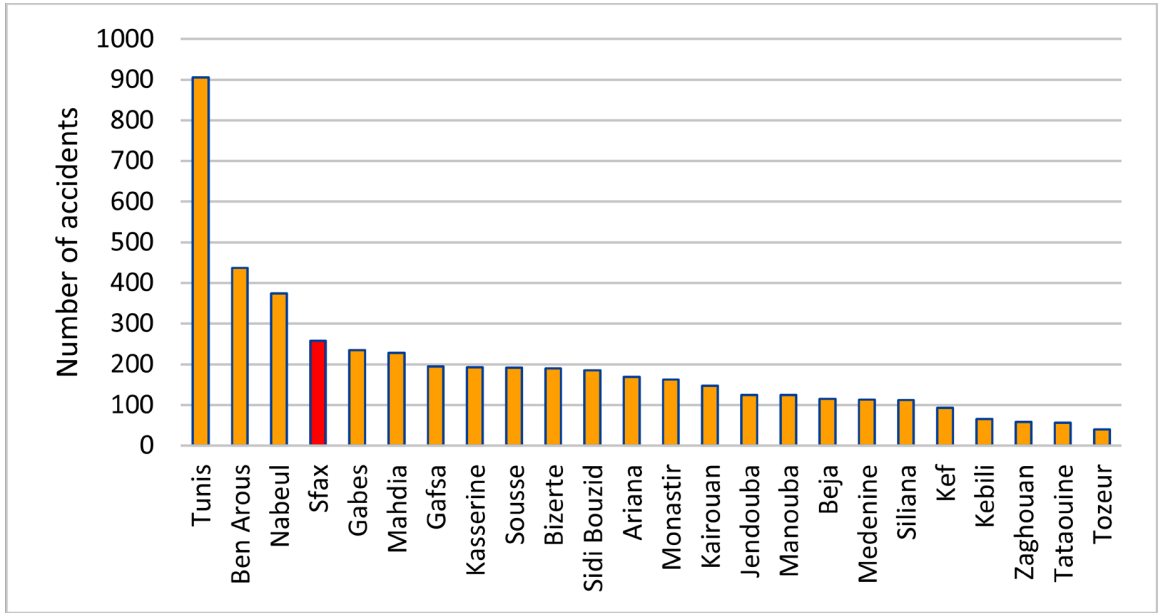

Figure 3. Distribution of accident numbers in Tunisia by governorate in 2020. Data source: [18].

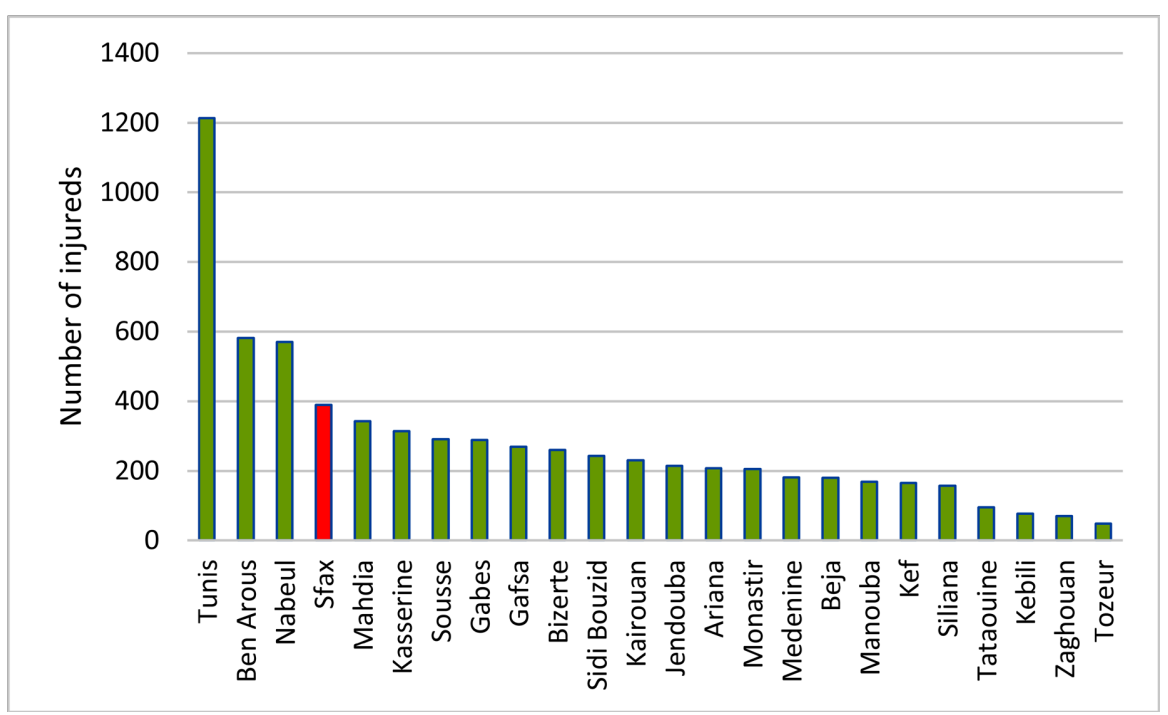

Figure 4. Distribution of the number of injuries in Tunisia by governorate in 2020. Data source [18]. 


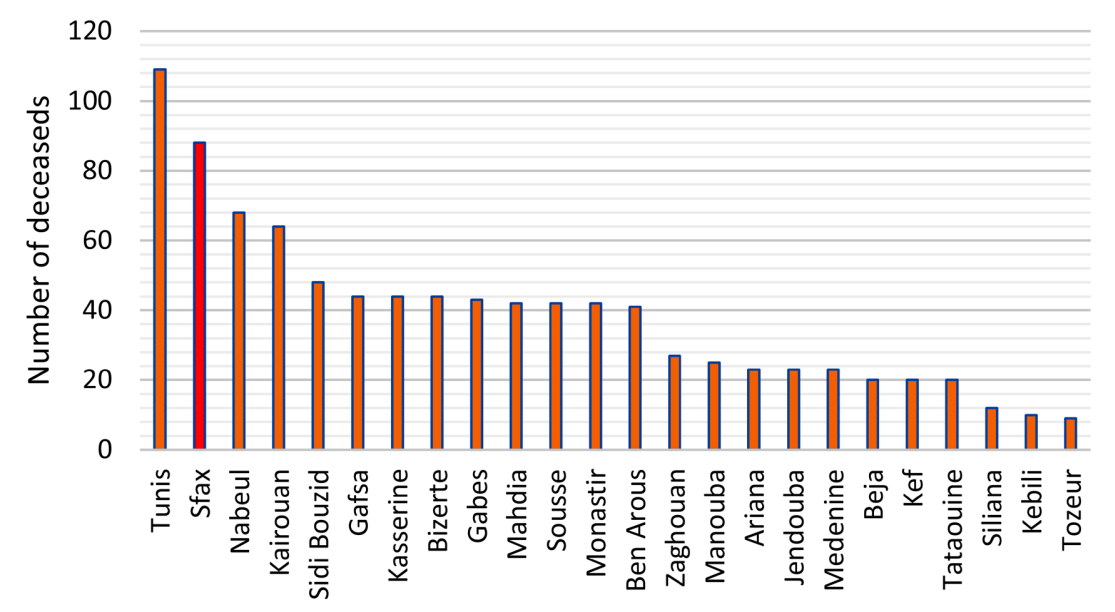

Figure 5. Distribution of the number of deceased in Tunisia by governorate in 2020. Data source: [18].

characteristic rurality of roads. Indeed, the large area of the governorate means that long distances from roads are to be found in rural areas, where speeds are very high, hence the severity of accidents.

The governorate of Sfax has an average of one accident per 1465 inhabitants. It ranks sixth in the country, considering, on the one hand, the size of this governorate, especially compared to the other governorates of Greater Tunis ( $\mathrm{Tu}$ nis, Ariana, Mannouba and Ben Arous) and those of the Sahel (Sousse, Monastir and Mahdia), and, on the other hand, given the reduced number of accidents in all southern governorates and most northern and western governorates (Figure 6).

A review of Figure 6 and Figure 8 shows that, at the national level, there is a relationship between the distribution of traffic accidents and the distribution of the number of populations. Indeed, coastal governorates, which are characterized by high population numbers and high urbanization rates [13] [22], have high accident numbers. On the other hand, most of the Western and Southern governorates, which have low rates of urbanization and population numbers [23], have low accident numbers. The Central East and North East governorates also have dense road networks and very heavy traffic from which they experience more traffic accidents (Figure 7) [21].

This relationship between traffic accidents and population, is also expressed in the governorate of Sfax. The correlation coefficient $\mathrm{R}$ is 0.87 . This relationship is relatively strong in that the coefficient of determination $R^{2}$ is 0.78 . The number of accidents is also strongly correlated with the rate of urbanization with a correlation coefficient $R$ equal to 0.76 , that of the determination $R^{2}$ of the order of 0.56 .

According to statistics from the NORS, $80 \%$ of accidents in the governorate of Sfax are in the Great Sfax and only $20 \%$ occurred outside this agglomeration. The number of accidents is also proportional to the population density. The delegations of Greater Sfax (Sfax Madina, Sfax Ouest, Sfax Sud, Sakiet Eddair, 


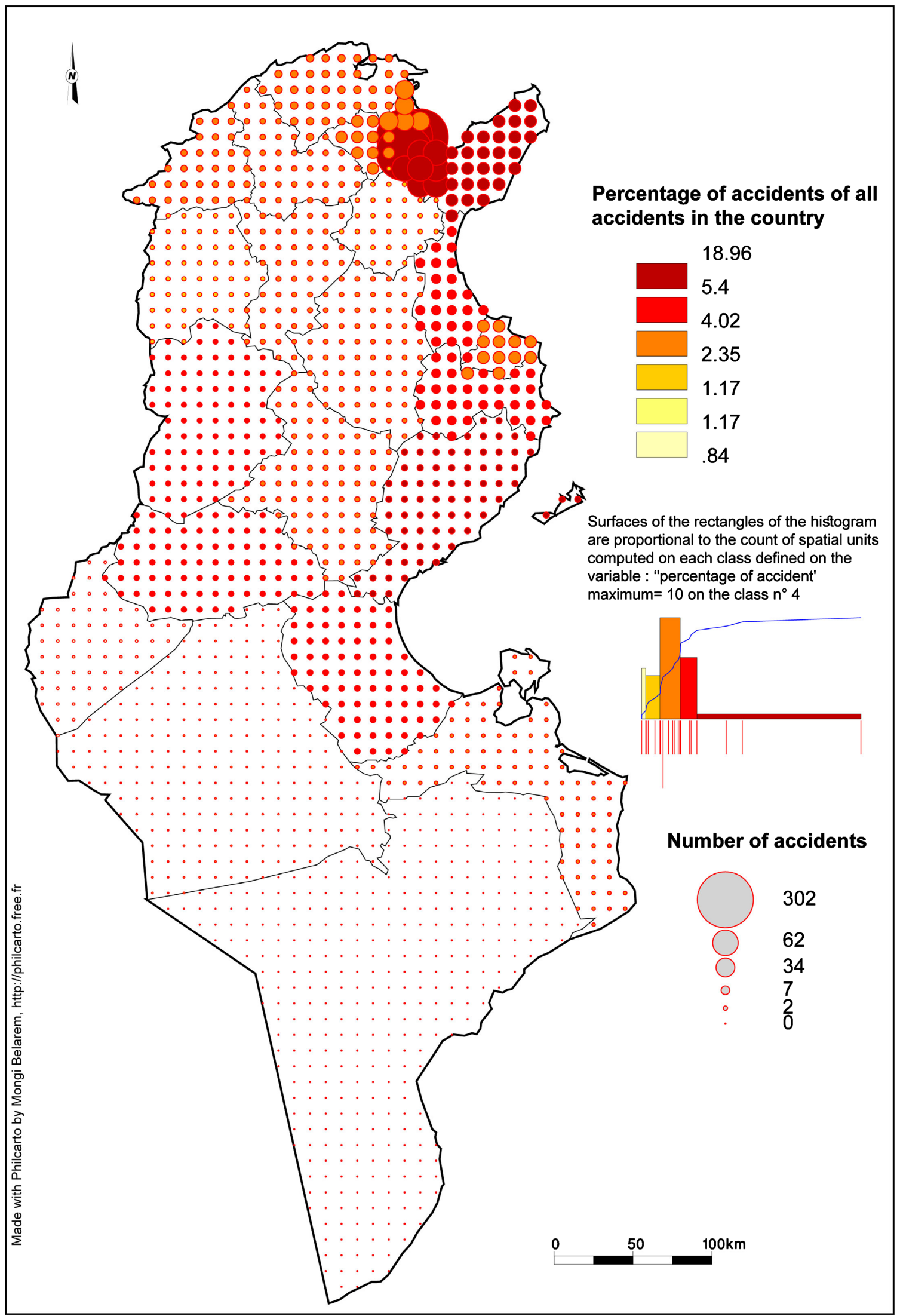

Figure 6. Distribution of accident in Tunisia by governorate in 2020. Data source [18]. 


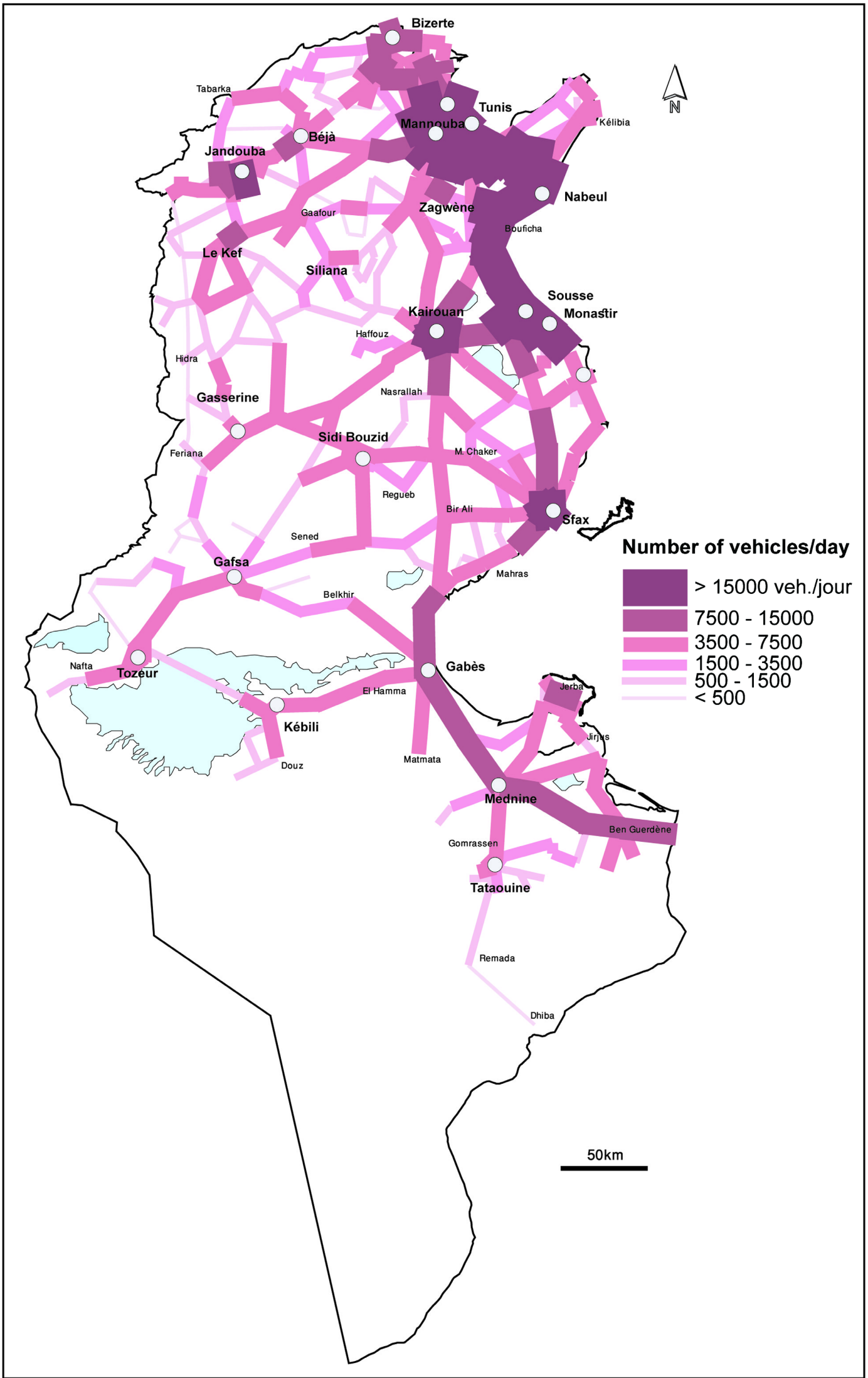

Figure 7. Road traffic in Tunisia in 2007. Source [19] [21]. 


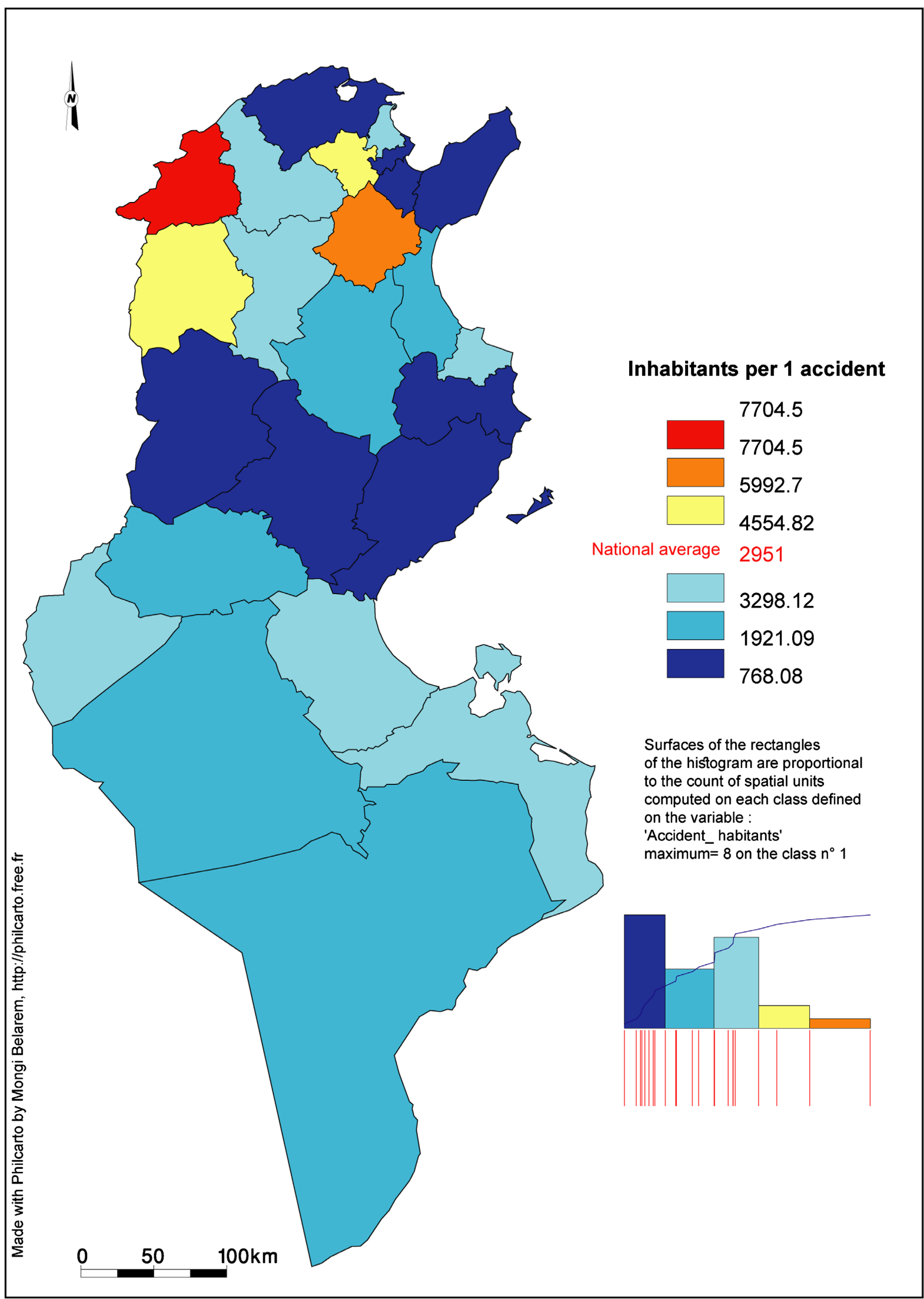

Figure 8. Distribution of the average population per accident in Tunisia by governorate in 2020. 
Sakiet Ezzit) have the highest population densities, compared to neighbouring delegations (Amra, Jebeniana, Hencha, Menzel Chaker, Agareb, Bir Ali Ben Khalifa, Skhira and Ghraiba) (Figure 9 and Figure 10).

The number of accidents is also proportional to the rate of motorization (Figure 11) with a coefficient of correlation of 0.69 , but this relationship is low. Generally, the delegations of the Greater Sfax (Sfax Madina, Sakiet Ezzit, Sakiet Eddair, Sfax Gharbia, Sfax Sud and Thyna) have high motorization rates. Peripheral delegations have relatively low accident numbers with low rates of motorization. Figure 12 shows that accidents are more related to rates of motorization in urban areas than in rural areas [12] [24].

\subsection{Distribution of Accidents, Injuries and Deceased by Type of Road}

To get a sense of the road effect on accidents, injuries and deceased, it is useful to understand the structure of the road network, which has generally been in decline over the past few years throughout Tunisia and especially in the governorate of Sfax (Figure 14) [24].

In Sfax, "five categories of roads make up the road network within the governorate of Sfax" [26] [27] (Figure 13 and Figure 15):

- Highway: a single highway (A-1) crosses the Sfax governorate and connects

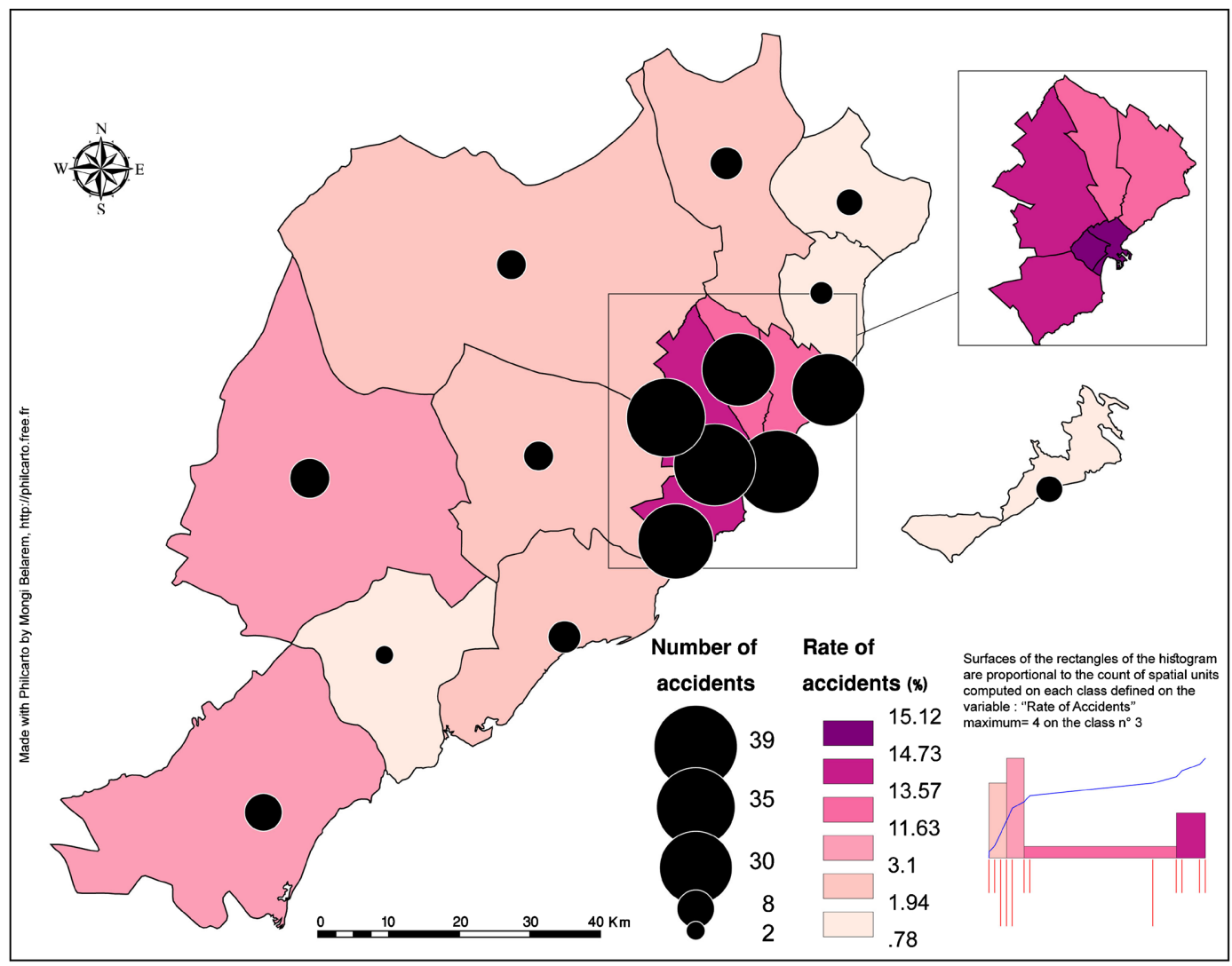

Figure 9. Distribution of traffic accidents in the Sfax governorate and the proportion of each delegation of all accidents. Data source [18]. 


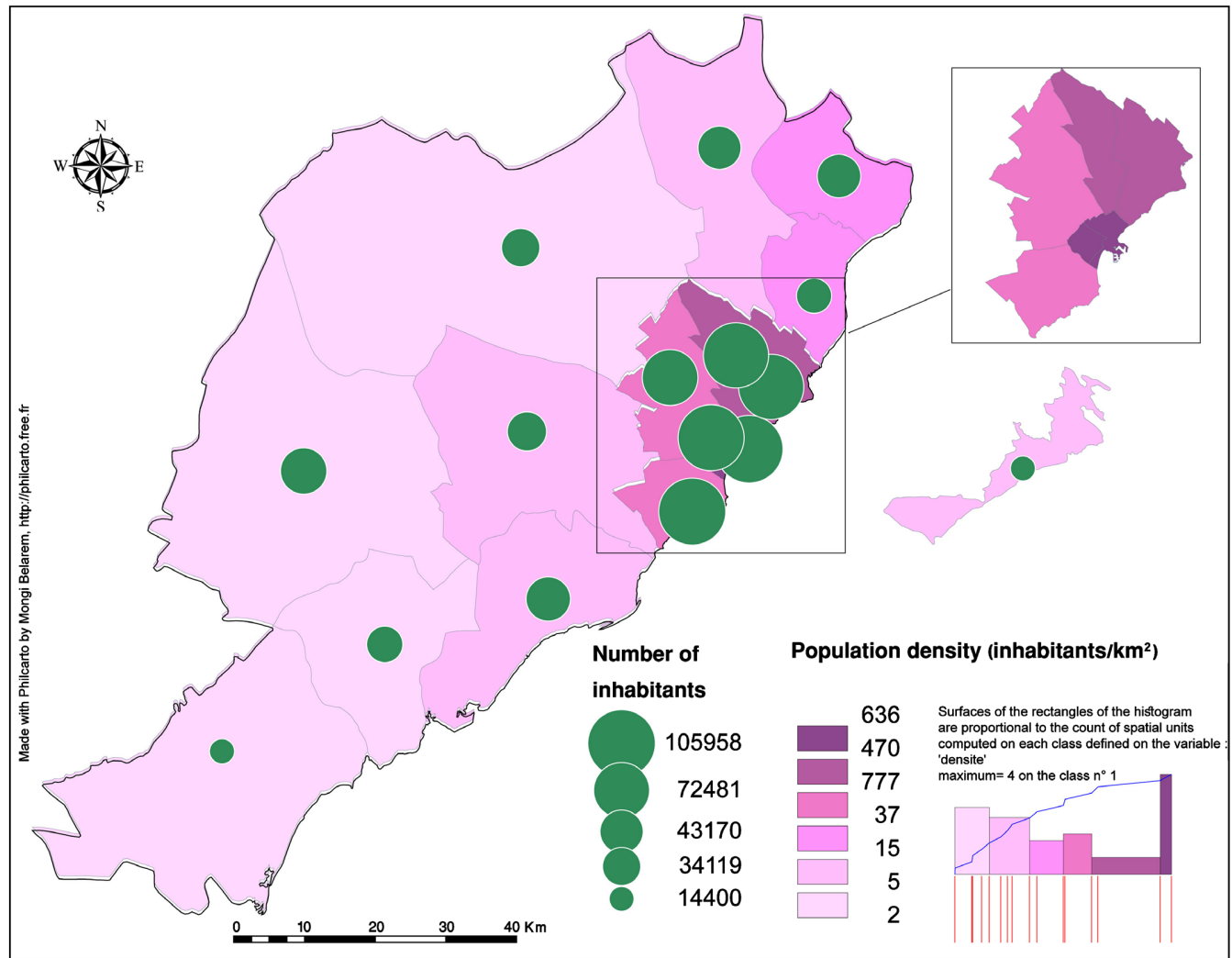

Figure 10. Population size and density in Sfax Governorate by delegation in 2014. Data source [18].

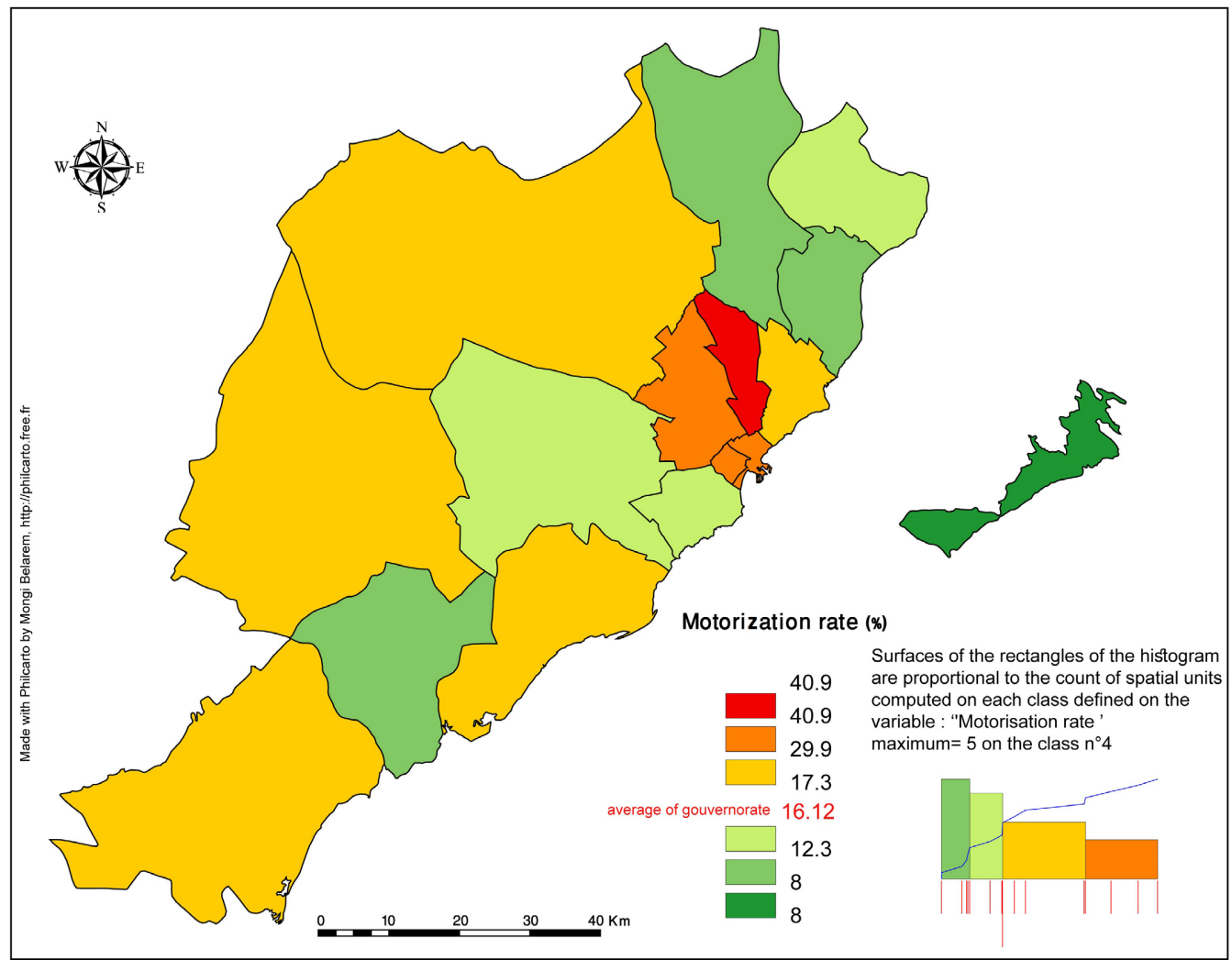

Figure 11. Motorization rate in Sfax governorate by delegation in 2014. Data source [25]. 


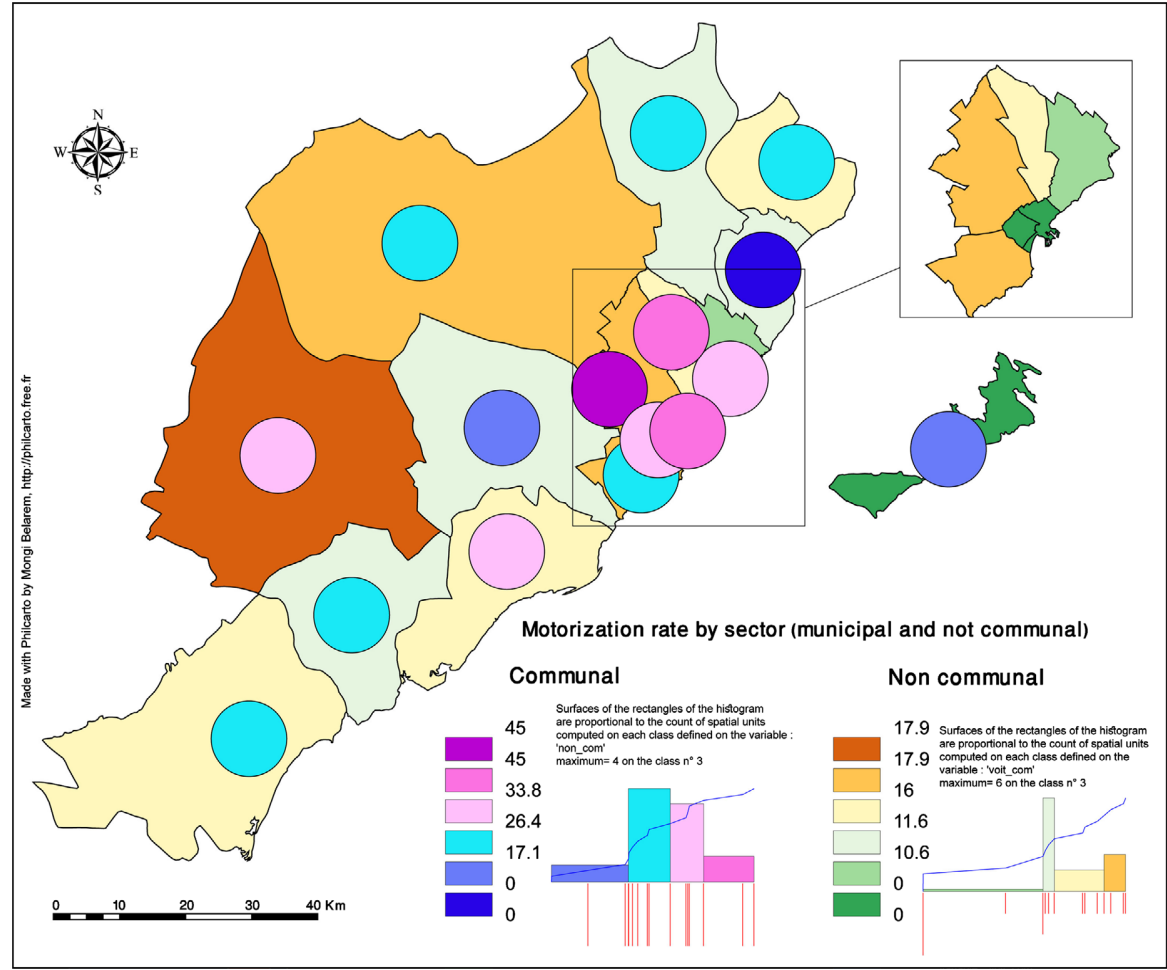

Figure 12. Motorization rate in the governorate of Sfax by communal or non-communal environment in 2014. Data source [25].

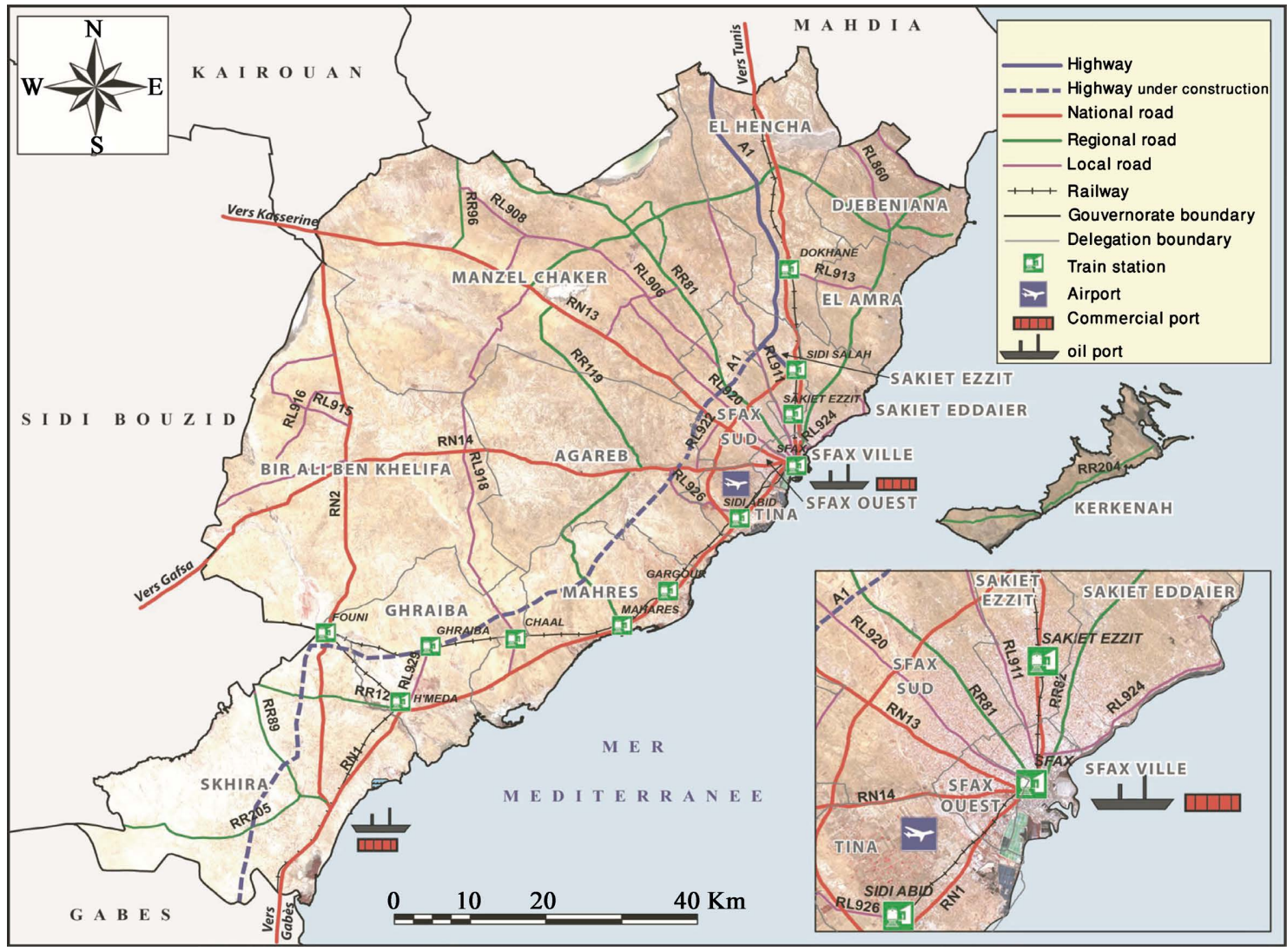

Figure 13. Distribution of roads by type in 2009. Source [26]. 


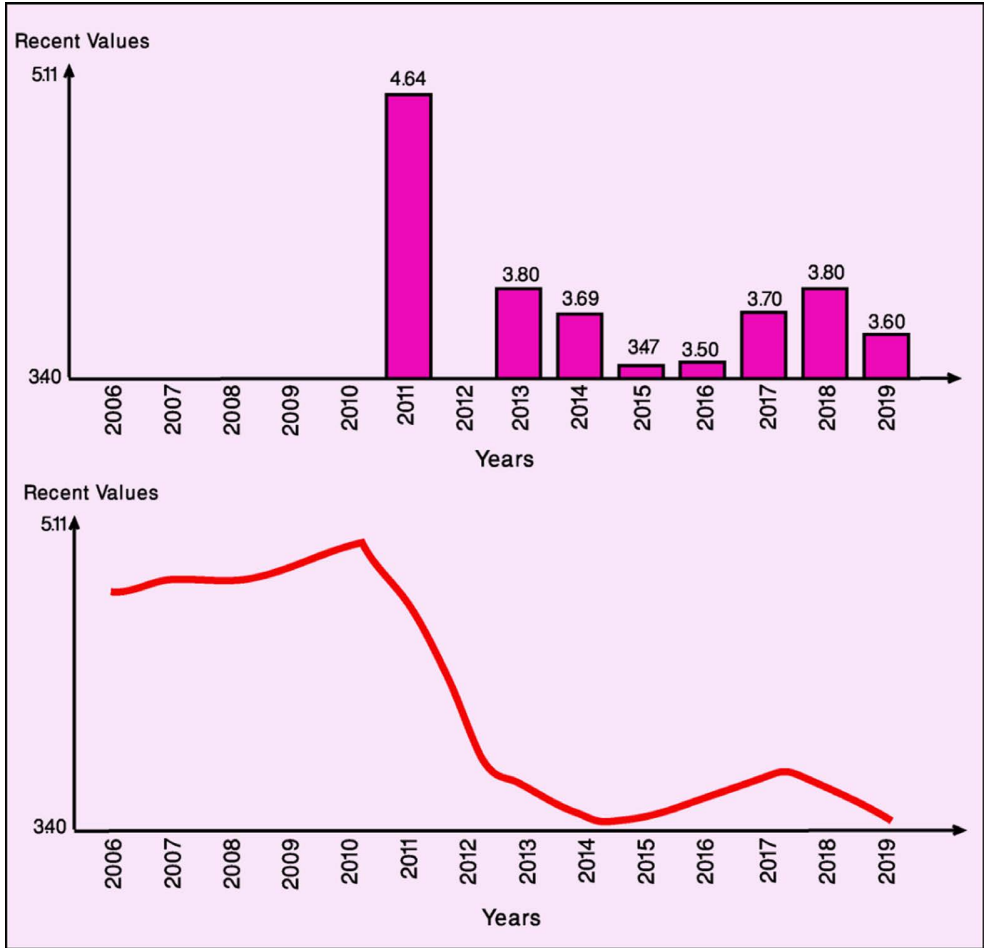

Figure 14. Quality of roads in Tunisia between 2006 and 2019 1(low) - 7(high). Source [24].

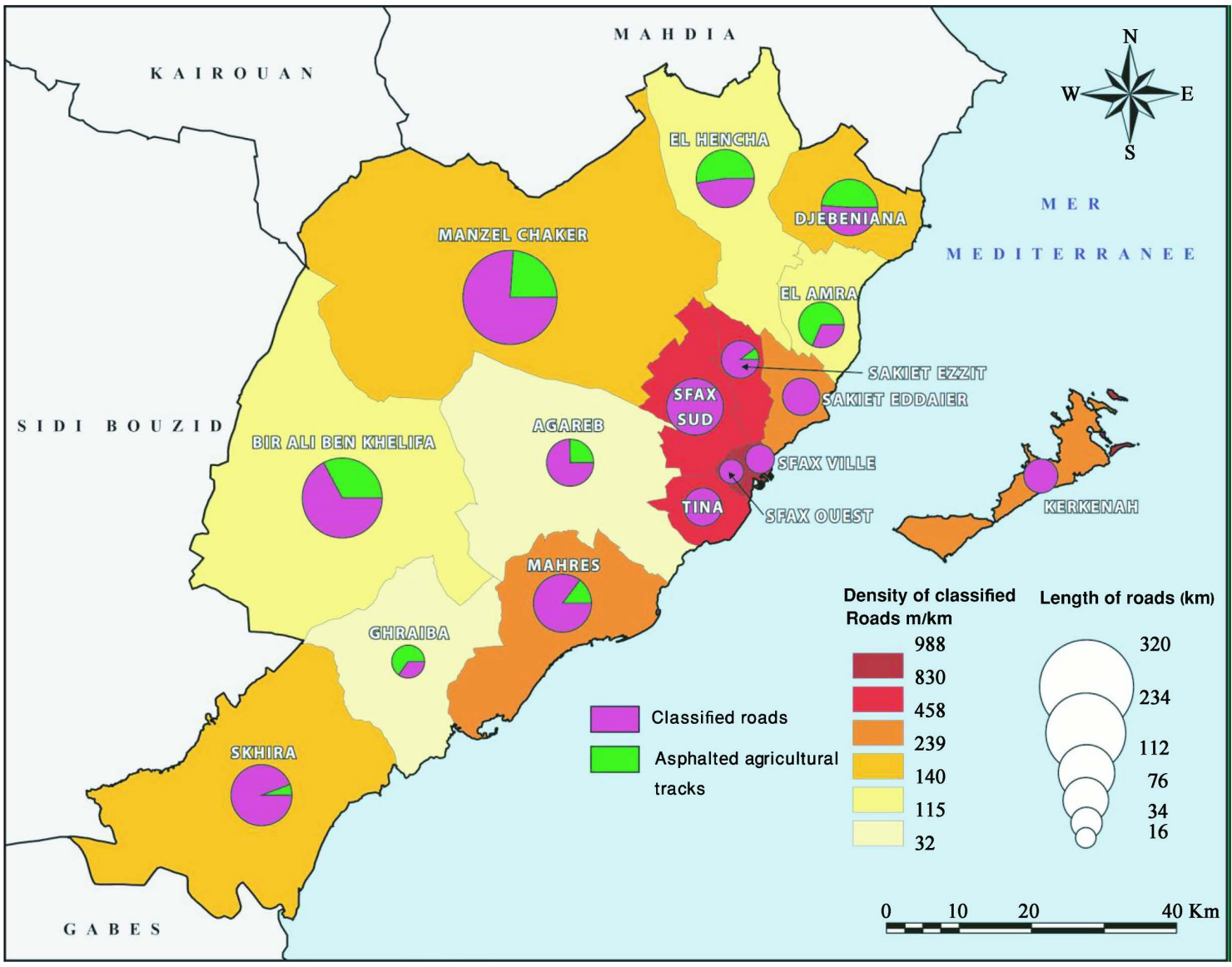

Figure 15. Distribution of roads in Sfax governorate in 2009 by type and by delegation. Source [26]. 
the region to the Sahel, Cap Bon and Greater Tunis. The extension of this highway to the south was not finalized until May 2018. It connects Sfax to Gabes, then to Medenine and finally to Libyan territory, via the crossing point of Ras Jedir.

- The National Roads (NR): four national roads cross the governorate of Sfax. The first, the National Road 1 (NR-1), connects the region to all the coastal agglomerations of the country, from Tunis to Ras Jedir, via Sousse, Gabès and Médenine. The second, the National Road 2 (NR-2), ensures the junction of the governorate to the Center of the country, in particular to Kairouan and Enfidha. The third (NR-13) connects the Sfax region with the Central-West of the country, up to the Algerian borders, via Sidi Bouzid and Kasserine. The last National Road (NR-14) connects Sfax to the southwest of the country, including the Gafsa region.

- Regional Roads (RR): there are eight (RR-81, RR-82, RR-89, RR-96, RR-119, RR-124, RR-204 and RR-205), which act as liaison between the various delegations of the governorate. Only, the delegation of Bir Ali Ben Khlifa which is not served by a regional road, is crossed by NR-2 and NR-14.

- Local Roads (LR): 26 local roads (LR-904 to LR-929) connect small towns to the local, regional and national road network.

- The tracks: mostly agricultural not bituminated. The asphalted agricultural tracks did not exceed $402 \mathrm{~km}$ throughout the governorate in 2009, of which almost all (98\%) is located in the hinterland of Sfax (Figure 15) [26] [27].

In 2014, the delegations of the Greater Sfax accumulated $345 \mathrm{~km}$ of asphalted roads including $65 \mathrm{~km}$ of agricultural tracks while the 10 peripheral delegations concern $1765 \mathrm{~km}$ (or $83.6 \%$ including $751 \mathrm{~km}$ of agricultural tracks). The delegation of Menzel Chaker occupies the first place in terms of asphalted tracks $(418 \mathrm{~km})$, then, in second position arrives Bir Ali Ben Khlifa $(283 \mathrm{~km})$ and then Skhira $(190 \mathrm{~km})$. The length of the road network is therefore closely related to the size of the area covered by the peripheral delegations [26] [28].

Road density reached its highest level in the delegations of the Greater Sfax $\left(88 \mathrm{~m} / \mathrm{km}^{2}\right)$ in 2009 . However, and on the same date, the lowest road density is recorded in the delegation of Menzel Chaker with $150 \mathrm{~m} / \mathrm{km}^{2}$. The national roads are the busiest, especially the sections that connect Sfax to the other cities of the Northern and Central governorates of Tunisia. The closer one gets to the Greater Sfax and the focal center of the governorate, the regional road density intensifies and the congestion becomes more noticeable [26]. The road density is not balanced between the Greater Sfax region and the rest of the governorate. Generally speaking, the roads that provide mobility in the governorate suffer from under-sizing and a lack of maintenance leading to its degradation. In addition, there is a significant proportion of agricultural runways that are not yet paved. "Mobility problems are concentrated in urban areas, particularly in the Greater Sfax. Transit failure largely explains congestion problems in the governorate" [27]. The number of accidents, injuries and deceased is positively related to road traffic. The greater the traffic, the greater the number of accidents. "The 
road traffic map in the Sfax Governorate indicates that the maximum daily traffic is typical of the national roads in the Sfax city center (Figure 16). Road traffic reached 22,581 vehicles/day on the section of the NR-1 connecting the city center to Ring Road 11 in the direction of Gabès" [26]. On the same line, between Ring Road 11 and Mahras, traffic drops to 14,925 vehicles/day, then to about 8000 vehicles/day on the rest of the NR-1 line. "Northbound traffic on the NR-1 is greater than southbound traffic and reaches 31,839 vehicles/day at Ring Road 4 and drops sharply to 15230 vehicles/day, just north of the same ring road (4), as NR-1 branches into several regional and local routes to Mahdia, Sousse and Kairouan, reducing the burden" [26].

Traffic could have been much higher there if NR-1 was not supported by RR-82 towards Mahdia (9107 vehicles/day) and LR-881 towards Jebeniana (12,984 vehicles/day) (Figure 16). In the direction of the central-west and the southwest of the country, the road traffic reached respectively 9856 vehicles/day on the NR-13 and 9765 vehicles/day on the NR-14. The daily flow of vehicles/day is rapidly decreasing on all roads, moving away from the city center towards the hinterland of Sfax (Figure 16) [26].

The distribution of traffic accidents by type of road shows that agglomeration's roads occupy the first place with nearly 65 accidents. This type of road also has the highest number of injured (24 injured). This is largely due to the high density of the road network and the fairly high traffic in the agglomerations.

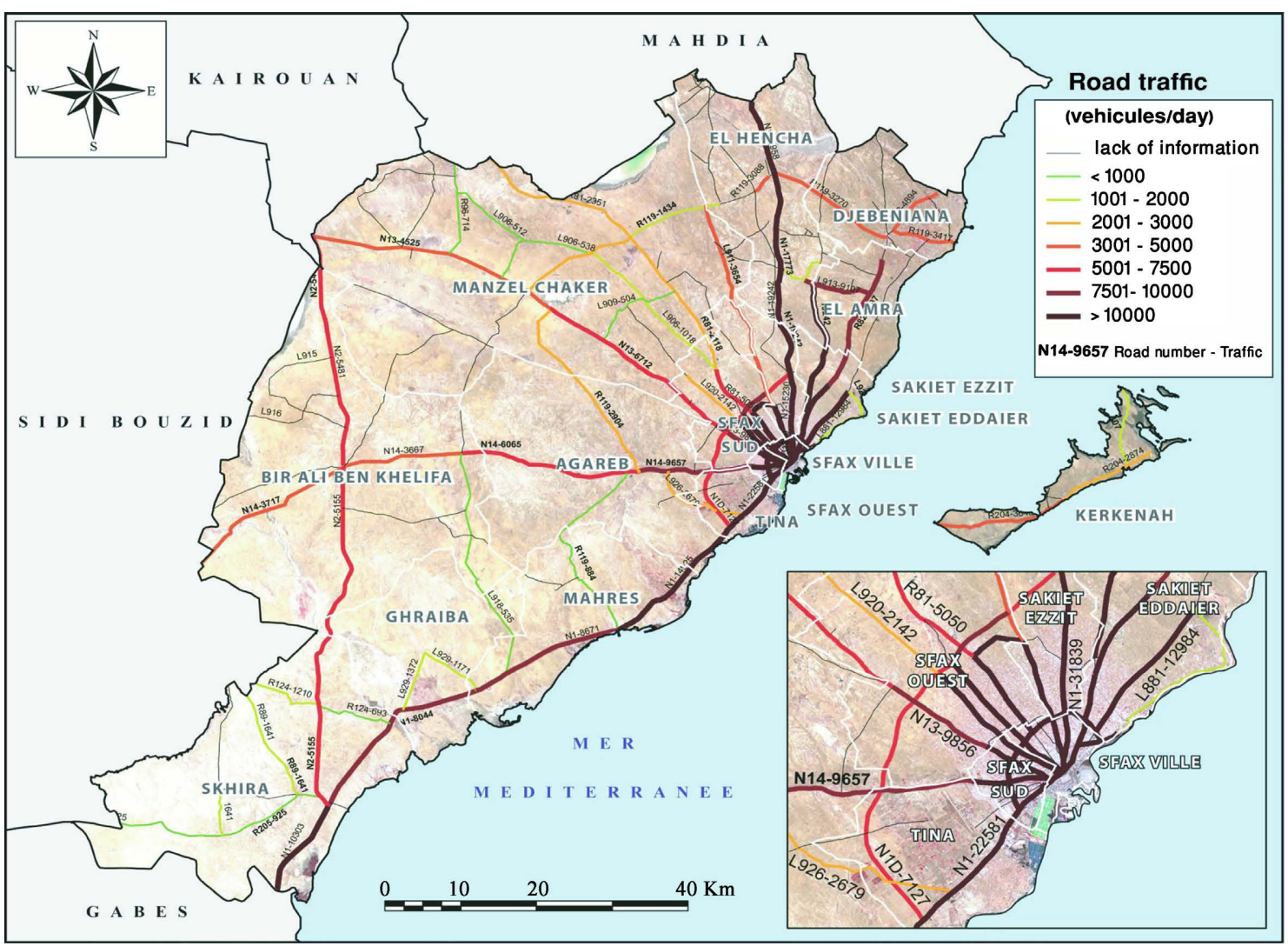

Figure 16. Road traffic in the Sfax governorate. Source [26]. 
National roads have the second highest number of accidents (63) and injuries (20), but the highest number of deceased (Figure 17). They are therefore more dangerous. The importance of traffic on national roads, the rural aspect of this type of road, and the very excessive or inappropriate speeds explain this gravity. Local roads are the third largest number of accidents, injuries and deceased. This place, relatively advanced, is explained by the length of the network, the importance of traffic and also by the rural aspect of these roads.

\subsection{Distribution of Accidents, Injuries and Deceased by Cause}

A "road accident can have several causes: human, meteorological or technical. Nevertheless, the human factor is paramount and affects more than 9 out of 10 accidents. Human causes come far ahead of other types of causes. The most common human causes are alcohol, speed, fatigue or drowsiness in nearly $8 \%$ of fatal accidents" [29]. Distraction is also a human factor in road accidents. The telephone behind the wheel increases the risk of having a bodily accident several times. Non-compliance with safety distances, failure to wear a seat belt, and failure to wear a helmet are also important causes of road accidents, in addition to other factors such as the age, occupation, and wisdom of the driver [17] [30] [31]. Other factors contribute either directly or indirectly to road safety. An example is "urban development that has an influence on economic and social activities and implicitly on traffic and associated risks" [32] [31]. Weather causes can increase the risk of a road accident. However, the weather is almost never the only cause of a road accident. The human factor is almost always present. Weather causes can be: the presence of fog, the lack of visibility caused by a climatic phenomenon such as rain and sand wind. Technical causes can increase the risk of road accidents. But, like weather factors, they are almost never the only causes of a road accident. The technical factor increases the risk of road accidents. These "causes are of two kinds: those relating to the condition of the vehicle and those relating to the condition of the infrastructure (poor road conditions in particular). The purpose of the roadside inspection obligation is to limit road accidents caused by vehicle technical failure" [32] [31].

In Sfax, and like all the other governorates of Tunisia, human factors are the most important. Lack of vigilance ranks first with almost $28 \%$ of accidents.
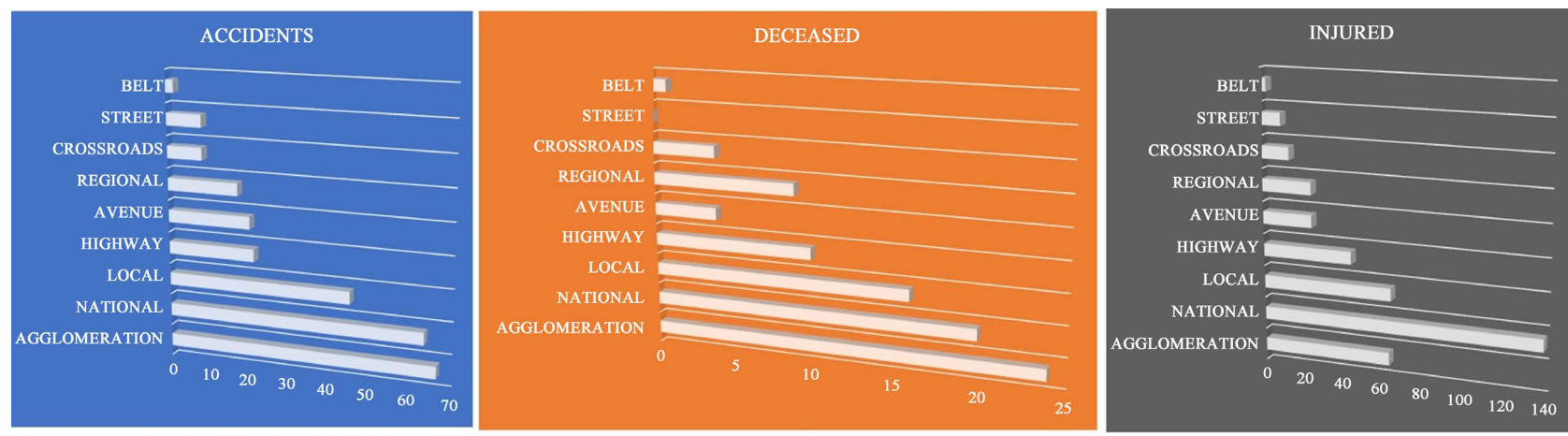

Figure 17. Distribution of accidents, deceased and injuries in Sfax Governorate by type of road in 2020. Data source [18]. 
Speed is the second factor with $15 \%$, non-compliance with the priority contributes with $8.5 \%$ of accidents, collision from the rear, the not driven to the right, crossing the road contribute with $5 \%$ for each factor. All accident factors are almost in the same range in terms of injuries and deceased (Figure 18).

\subsection{Distribution of Accidents, Injuries and Deceased by Means of Transport}

The numbers and proportions of accidents, injuries and deceased differ depending on the mode of transport and the amount of traffic on each utility vehicle. The car is the most used means to move by road from one point to another in all countries, especially in Tunisia where other modes of transport (rail, maritime, air...) have low contributions. This means is considered the most dangerous means [27]. According to the DGAT (2013), road traffic in the Sfax governorate differs from one region to another according to the types of utilities (Figure 20). Indeed, heavy trucks avoid the city center of Sfax and take the ring road 11 to pass from the NR-1 north to the NR-1 south (Figure 20(C)). For example, heavy-duty truck traffic registers its maximum (3302 vehicles/day) on NR-1, north of the Governorate (Figure 20(C)). On the other hand, the traffic of light commercial vehicles is relatively more concentrated in the city of Sfax, and reaches its maximum (29,824 vehicles/day on the NR-1), at the level of ring road 4 (north). Traffic is also quite high by continuing the NR-1 towards the southern suburbs of Sfax (28,729 vehicles/day) (Figure 20(B)). Traffic is more concentrated in the city center of Sfax for cycles and motorcycles, and reaches its maximum on the NR-14, between the city center and ring road 4 (5977 cycles and motorcycles/day) (Figure 20(A)). Figure 20(D) shows that light commercial vehicle traffic is dominant and cycles and motorcycles are concentrated in cities, including Sfax and Kerkennah [26].
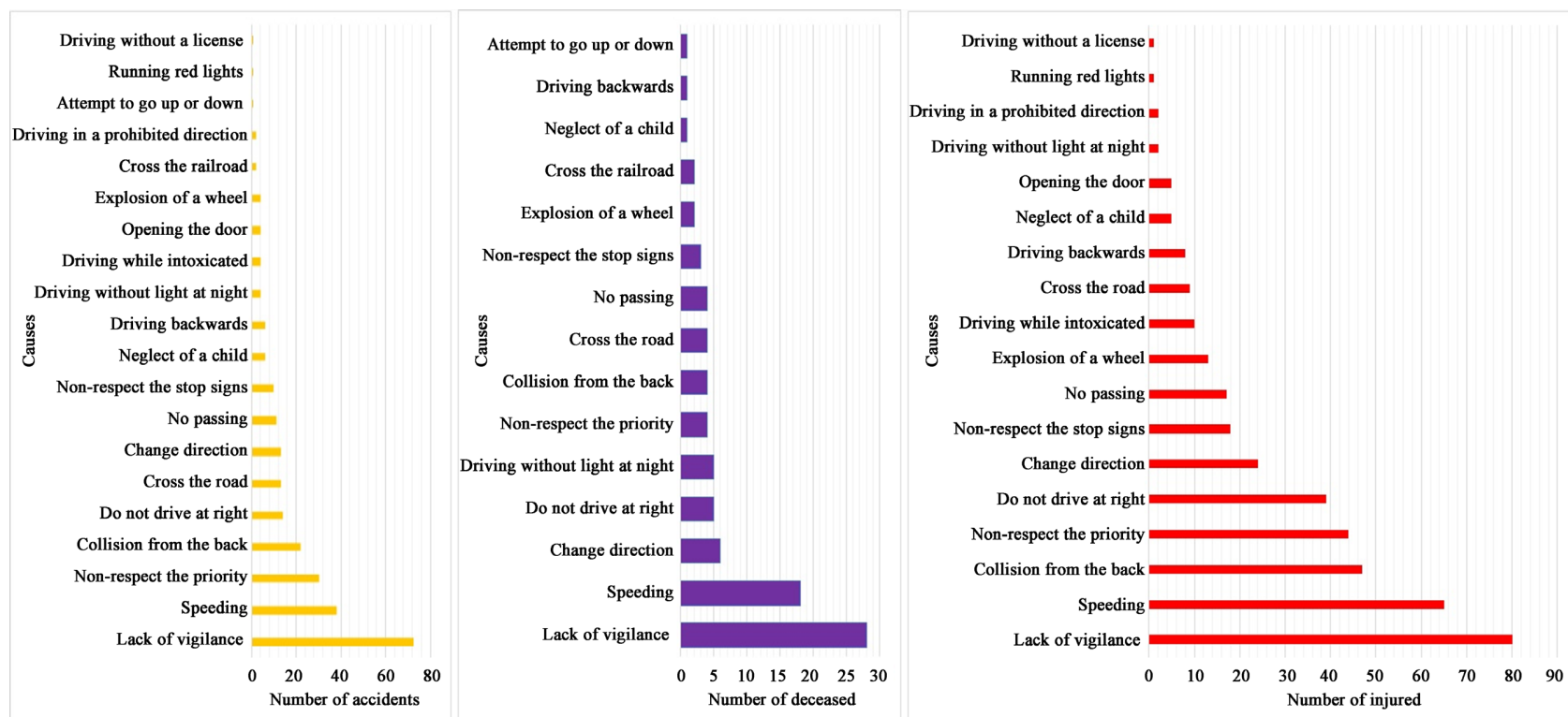

Figure 18. Distribution of accidents, deceased and injuries in Sfax governorate by causes in 2020 [18] (data source: NORS, 2021). 


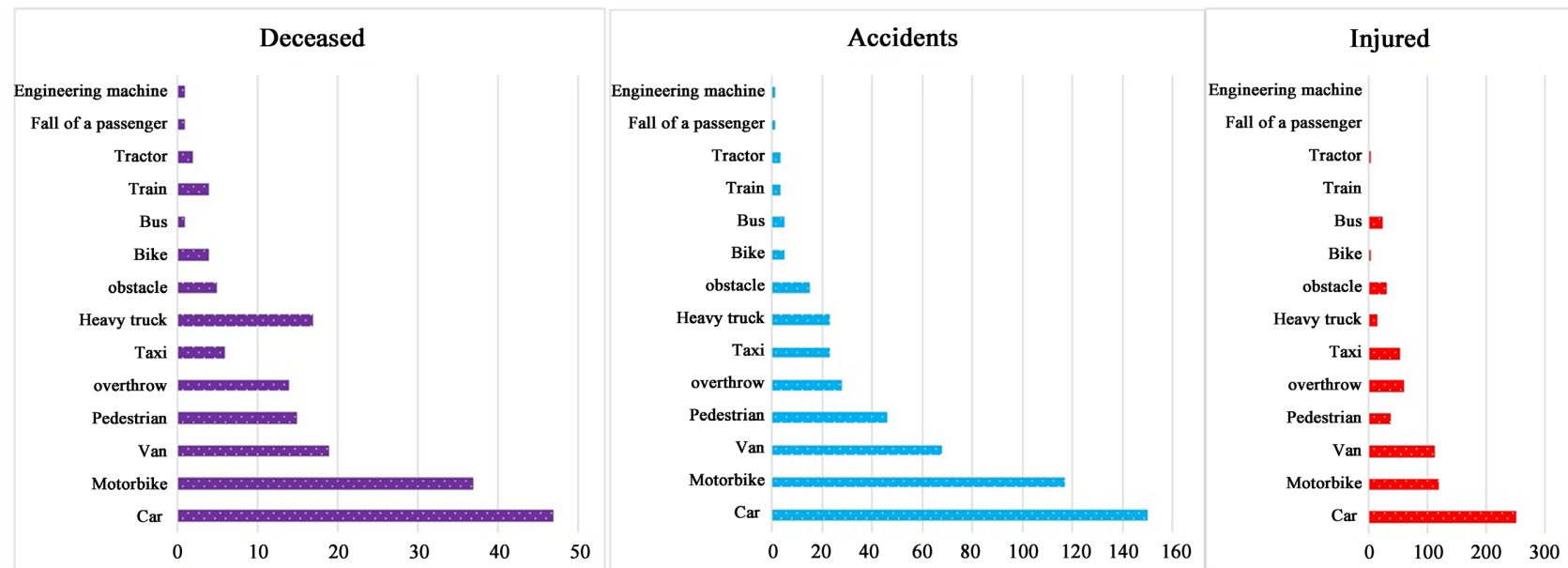

Figure 19. Distribution of accidents, deceased and injuries in Sfax governorate by means of transport in 2020. Data source [18].
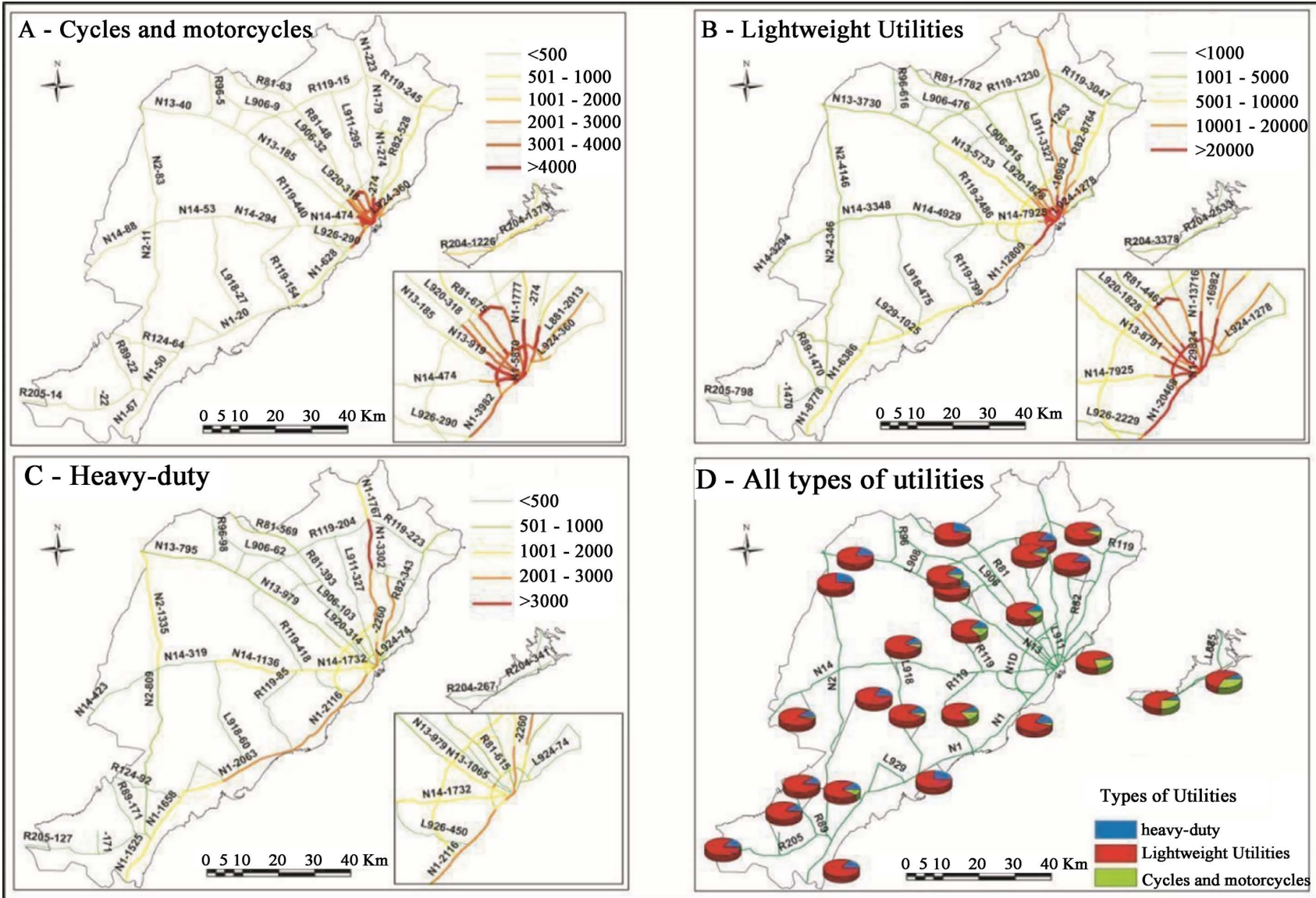

Figure 20. Road traffic by type of utility in Sfax Governorate. Source [26].

Light-duty vehicles contribute the largest share of accidents. Four elements contribute together with $80 \%$ of the number of accidents (the car $34 \%$, the motorcycle $24 \%$, the van $14 \%$ and the pedestrian $10 \%$ ). The other means and elements contribute together with $20 \%$ of the number of accidents (rollover, taxi, heavy truck, obstacle, bike, bus, train, tractor, fall of a passenger, engineering machine) (Figure 19). As regards the number of injuries and deceased, all these 
means of transport keep almost the same ranks as those of accidents with varying proportions. These contributions of the means of transport in the number of accidents, injuries and deceased can even be explained in part, with the importance of the traffic of these means of transport.

\subsection{Distribution of Accidents, Injuries and Deceased by Month and Day}

In 2020 in Sfax, it is in April that accidents are the least frequent (6 accidents) and in October that they are the most numerous (34 accidents). Autumn and summer periods are more marked by more accidents with 73 and 72 respectively. In April, there were only two wounded, but in August and December, there were 50 for each of the two. The highest proportion of injuries (30\%) is recorded in the summer, followed by the fall period with $28 \%$, whereas in the spring the lowest proportion is recorded (15\%) (Figure 21 and Figure 22). In general, the importance of accidents, in summer and autumn, can be explained by the growth in the number of trips, especially between regions and towards coastal and tourist areas, which reaches its maximum in summer and by the excessive or unsuitable speed.

Thursdays and Wednesdays in 2020 are the days with the most accidents (45 and 46 respectively). Mondays are the first in number of wounded with 70 followed by Thursdays with 66 wounded. Sunday has the highest number of deaths (22). The weekend accounts for $30 \%$ of accidents, $26 \%$ of injuries and $43 \%$ of those killed (Figure 23).

\section{Conclusion and Recommendations}

According to the analysis of the accident phenomenon in the governorate of Sfax, we can put forward the following remarks:

- The Greater Sfax alone accounts for more than $80 \%$ of the number of accidents

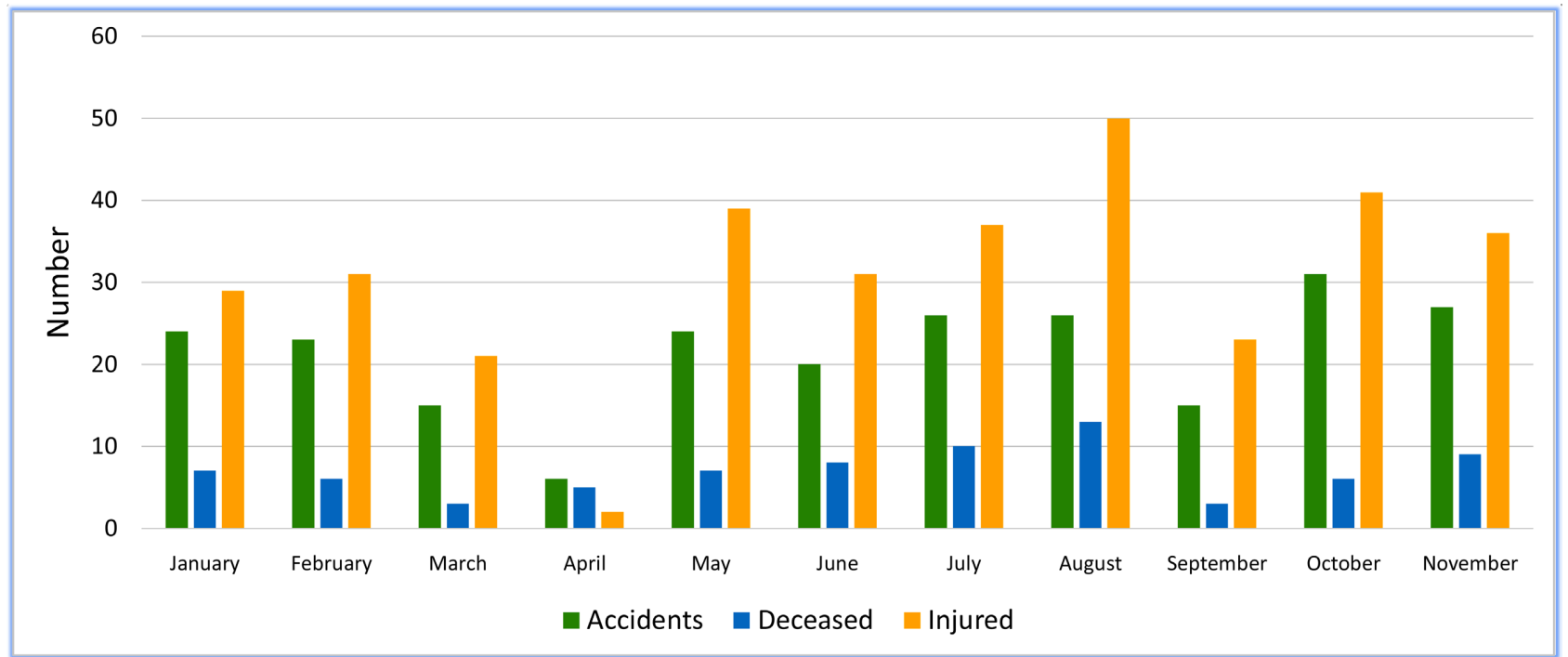

Figure 21. Distribution of numbers of accidents, deceased and injuries in Sfax Governorate by month in 2020. Data source [18]. 


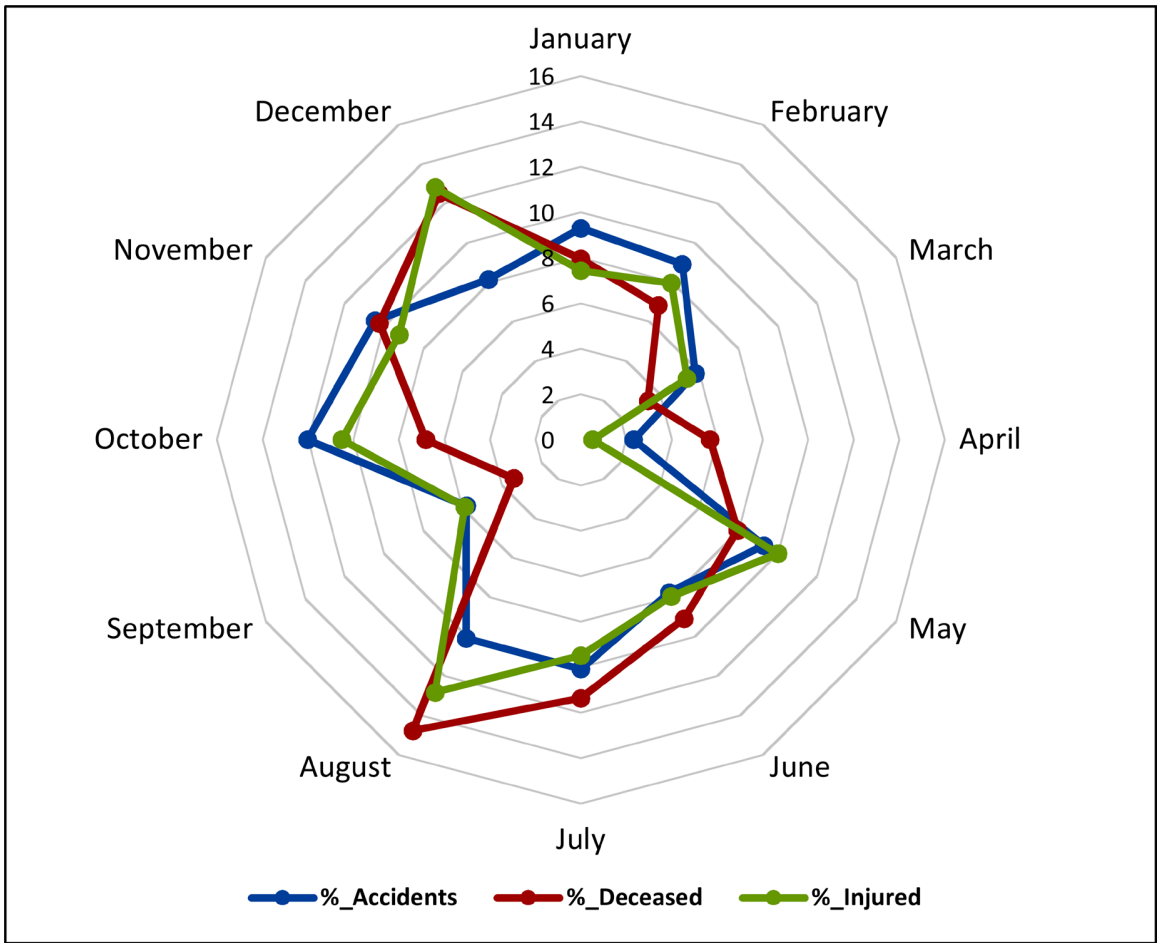

Figure 22. Distribution of percentage of accidents, deceased and injuries in Sfax Governorate by month in 2020. Data source [18].

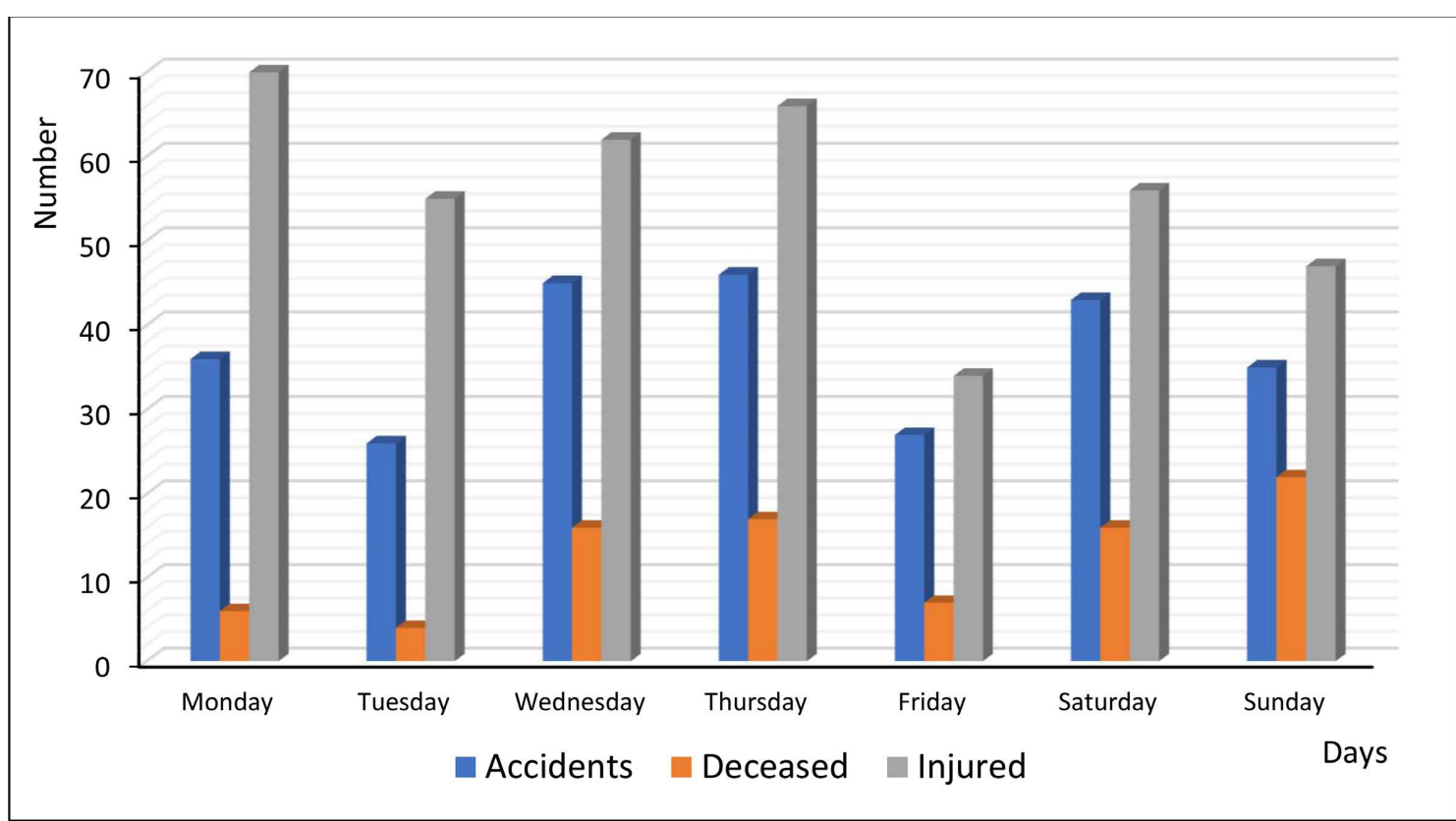

Figure 23. Distribution of accidents, deceased and injuries in Sfax Governorate by day in 2020. Data source [18].

in the governorate.

- The closer we get to the urban environment, the more the number of accidents increases, and on the roads of the agglomerations, the more the number of accidents increases.

- On national roads, the proportions of accidents and their severity are greater 
than those on local roads and agricultural tracks.

- The length of the road network is not a strong explanation for the number of accidents.

- The highest accident densities are in the most densely populated areas.

- The delegations, which are the most equipped with means of transport, have a larger number of accidents.

- The car is the most serious means of transportation in the number of accidents, injuries and deaths. After the car, the motorcycle is second and the truck third.

- In October, there are more accidents, but in August, there are more injuries and deceased.

- On Thursdays there are more accidents, on Mondays there are more injuries, and on Sundays there are more deaths

This serious situation calls for urgent and effective interventions by the authorities in various ways to limit losses and to ensure a safe living environment for road users and citizens. These actions must be highlighted by the awareness of road users by several measures such as compliance with the rules of the road, the range of the safety belt or the approved helmet, compliance with the minimum safety distances, speed limits and stops and red lights, driving without using drugs... improving the road network (extending the network, bitumen, road signs...) and technical intervention on the network and on vehicles.

\section{Conflicts of Interest}

The author declares no conflicts of interest regarding the publication of this paper.

\section{References}

[1] Abdulhafedh, A. (2017) Identifying Vehicular Crash High Risk Locations along Highways via Spatial Autocorrelation Indices and Kernel Density Estimation. World Journal of Engineering and Technology, 5, 198-215.

[2] Baker, S., Whitfield, R.A. and O’Neill, B. (1987) Geography Variations in Mortality from Motor Vehicle Crashes. The New England Journal of Medicine, 316, 1384-1387. https://doi.org/10.1056/NEJM198705283162206

[3] Boucher, C. (2003) La sécurité sur les autoroutes éclairées: les accidents avec Lampadaires, cas des autoroutes 10 et 15 en périphérie de Montréal. Mémoire présenté pour l'obtention du grade de Maître ès sciences (M.Sc.) en géographie, cheminement Géographie Humaine, Université de Sherbrooke, Québec.

[4] Bonnet, E., Fillol, A., Nikiema, A., et al. (2008) Évaluation des inégalités sociales de santé des traumatisés de la route à Ouagadougou au Burkina Faso Santé publique. Santé Publique, 30, S131-S137.

[5] Charfi, F. (2016) Stratégie Sfax 2030: De la vision stratégique au plan d'actionsRapport final. Association de Développement Solidaire de Sfax ADSS avec l'appui de l'association allemande Friedrich Ebert Stiftung, 180 p.

[6] http://ins.tn/enquetes/recensement-general-de-la-population-et-de-lhabitat-2014

[7] http://www.onsr.nat.tn/ 
[8] Al Muzahmi, S.N.K. (2015) Mortality Patterns in Oman: Demographic and Epidemiological Review. PhD Thesis, School of Public Health, The University of Queensland, Brisbane. https://doi.org/10.14264/uql.2015.889 https://espace.library.uq.edu.au/view/UQ:369205

[9] https://globaljournals.org/GJMBR_Volume16/E-Journal_GJMBR_(G)_Vol_16_Issu e_1.pdf

[10] https://www.theglobaleconomy.com/Tunisia/roads_quality/

[11] Madouda, H., Alouache, O. and Ait Taleb, A. (2021) Principaux facteurs déterminant la sinistralité car en Algérie, Economic Researcher Review Volume 09 (Numéro 01), Algérie, Université 20 Août 1955-Skikda, 50-65. https://doi.org/10.35391/1894-009-001-004

[12] Ministère de l'Equipement et de l'Aménagement du Territoire (MEAT) (2014) Guide du transport durable en Tunisie. Observatoire Tunisien de l'Environnement et du Développement Durable, 49 p.

[13] Ministère de l'Equipement et de l'Environnement-Direction Générale de l'aménagement du Territoire (MEE-DGAT) (2013) Atlas du gouvernorat de Sfax.

[14] http://www.justifit.fr/b/guides/droit-routier/causes-accidents-de-la-route/

[15] Moellering, H. (1973) The Journey of Death: A Spatial Analysis of Fatal Traffic Crashes in Michigan, 1969. Ph.D. Thesis, University of Michigan, Department of Geography, Ann Arbor, 184 p.

[16] Dhieb, M. and Belarem, M. (2016) Le découpage administratif tunisien: Entre enjeux politique et administratif et représentation citoyenne, in Colloque International: Maillages territoriaux, Démocratie et Élection, 30-38.

http://riate.cnrs.fr/wp-content/uploads/2017/01/Actes-de-conf\%C3\%A9rence_Mon astir2016_VF_090117.pdf

[17] Whitelegg, J. (1987) A Geography of Road Traffic Accidents. Transactions of Institute of British Geographers, 12, 161-176. https://doi.org/10.2307/622525

[18] Belarem, M. (2003) La mise en œuvre d'un SIG pour la gestion des déchets solides dans les communes du gouvernorat de Sfax. Mémoire de DEA, FSHS, $180 \mathrm{p}$.

[19] Belarem, M. (2011) Vers l'amélioration du système de transport dans le Grand Sfax de Sfax. Thèse de doctorat, Tunis Université de Tunis, FSHS, $480 \mathrm{p}$.

[20] Belarem, M. (2019) Cartographie des élections municipales tunisiennes de 2018 à l'échelle macroscopique: L'Exemple de la circonscription de Sfax 2. International Journal of Humanities and Cultural Studies, 6, 24.

https://www.ijhcs.com/index.php/ijhcs/article/view/3376/3119

[21] OMS (Organización Mundial de la Salud) (2018) Rapport de situation sur la sécurité routière dans le monde 2018: Résumé. WHO/NMH/NVI/18.20.

https://www.who.int/violence_injury_prevention/road_safety_status/2018/French-S ummary-GSRRS2018.pdf

[22] Belarem, M. (2020) Multi-Scalar Mapping of Potential Voters in Tunisia's 2019 Presidential Elections. Open Journal of Political Science, 10, 27-40.

https://doi.org/10.4236/ojps.2020.101003

[23] Bouhamed, N. (2018) Développement durable et management du secteur des transports en Tunisie: Diagnostic territorial pour un meilleur management de la sécurité routière-Etude du cas du Grand Sfax. Gestion et management. Université de Sfax, Sfax.

[24] Vandersmissen, M.-H., Morin, D., Thomas, I. and Pouliot, M. (1996) Aspects macrogéographiques des accidents de la route: essai de comparaison Québec-Belgique. 
Cahiers de géographie du Québec, 40, 49-66. https://doi.org/10.7202/022544ar

[25] Ben Fguira, S. and Belarem, M. (2021) Le Commerce de Proximité de la grande Distribution en Tunisie: Cas de la Chaîne Aziza. International Journal of Humanities Social Sciences and Education, 8, 53-68. https://doi.org/10.20431/2349-0381.0810007

[26] Ben Fguira, S. and Belarem, M. (2018) Quel avenir pour le logement social en Tunisie? Confins [En ligne], 36. https://journals.openedition.org/confins/13450

[27] Vandersmissen, M.-H. (2013) Analyse différenciée selon le sexe de l'accidentologie au Québec et de la mobilité à Québec.

http://www.bv.transports.gouv.qc.ca/mono/1148867.pdf

[28] Vandersmissen, M.-H., Villeneuve, P. and Thériault, M. (2001) Mobilité et accessibilité: Leurs effets sur l'insertion professionnelle des femmes. L'Espace géographique 2001/4 (tome 30), pages 289 à 305. HYPERLINK.

https://doi.org/10.3917/eg.304.0289\#xd_co_f=NWQ2ZTBmZTMtYzM0Zi00ODdjL Tk0MTQtYWRlZTU5N2VkNTk1 https://doi.org/10.3917/eg.304.0289

[29] Chouari, W. and Belarem, M. (2017) Enjeux de la Tunisie orientale: un territoire développé et un environnement à protéger. Confins, 30. [En ligne] http://journals.openedition.org/confins/11701

[30] www.statbel.fgov.be/fr/themes/mobilite/circulation/accidents-de-la-circulation

[31] Gilbert, T. (1979) Les risques d'accidents de la route. Economie et statistique, No. 117, 13-22. https://doi.org/10.3406/estat.1979.4293 https://www.persee.fr/doc/estat_0336-1454_1979_num_117_1_4293

[32] Raicu, S., Costescu, D., Burciu, S., Rusca, F. and Rosca, M. (2016) Road Accident Estimation Model in Urban Areas. Transport Problems, 11, 33-42.

https://doi.org/10.20858/tp.2016.11.3.4 